\title{
Advances in Forest Hydrology: Challenges AND OpPORTUNITIES
}

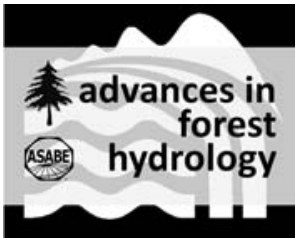

\author{
D. M. Amatya，K. R. Douglas-Mankin, T. M. Williams， R. W. Skaggs，J. E. Nettles
}

\begin{abstract}
Forests are an integral component of the landscape, and maintaining their functional integrity is fundamental for the sustainability of ecosystems and societies alike. Tools, innovations, and practices, analogous to those developed to improve agricultural production and quantify environmental impacts, are needed to ensure the sustainability of these forested landscapes as well as the ecosystem goods and services they produce. This article introduces ten technical articles on critical ecohydrologic processes, protection and restoration, and the effects of management practices on the hydrology and water quality of forests and forested wetlands, using both monitoring and modeling approaches. Prepared by experts in forest science, forest and agricultural hydrology, and water management, the studies reported in this special collection are concentrated in the Atlantic Coastal plain and focus on forests with shallow water tables. Experimental studies describe the effects of riparian vegetation harvest, human disturbance, and future climatic change on groundwater, the significance of emergent vegetation after harvest, and long-term hydrologic water balance of a managed pine forest. Modeling studies use the SWAT model to predict streamflow dynamics of a less disturbed, coastal forested watershed, and DRAINMOD to determine the impacts of minor silvicultural drainage on wetland hydrology and to improve wetland restoration. Finally, a study describes potential uncertainties associated with infrequent water sampling of nutrient loads from drained forested watersheds. This introductory article summarizes these studies of shallow water table forests and relates them to the broader field of forest hydrology, including its challenges and opportunities, while identifying pressing issues of land use and climate change. The results from these studies should help guide management and restoration of forest wetland ecosystems and direct future forest hydrologic research, including research in large prior converted agricultural landscapes.
\end{abstract}

Keywords. Agricultural landscape, Best management practices, DRAINMOD, Evapotranspiration, Forested wetlands, Hydrologic processes, Nutrient loading, Riparian buffer, Shallow water table, SWAT.

$\mathrm{F}$ Tor more than a century, agricultural and biological engineers have provided major advances in science, engineering, and technology to increase food and fiber production to meet the demands of a rapidly growing global population. Much of our agricultural land base originates from historically forested lands (Amatya et al., 2009), which have experienced dramatic declines, as well as periods of resurgence, over the past century, including in the south (U.S. Forest Service, 2011). The resulting landscape is a mosaic of agricultural, forest, and urban lands. Land use pressures, economics, markets, and environmental

Submitted for review in September 2011 as manuscript number SW 9359; approved for publication by the Soil \& Water Division of ASABE in November 2011.

The authors are Devendra M. Amatya, ASABE Member, Research Hydrologist, USDA Forest Service, Center for Forested Wetlands Research, Cordesville, South Carolina; Kyle R. Douglas-Mankin, ASABE Member, Professor, Department of Biological and Agricultural Engineering, Kansas State University, Manhattan, Kansas; Thomas M. Williams, Emeritus Professor, Baruch Institute of Coastal Ecology and Forest Science, Clemson University, Georgetown, South Carolina; R. Wayne Skaggs, ASABE Fellow, W. N. Reynolds and Distinguished University Professor, Department of Biological and Agricultural Engineering, North Carolina State University, Raleigh, North Carolina; and Jami E. Nettles, Research Hydrologist, Weyerhaeuser Company, Field Station, Columbus, Mississippi. Corresponding author: Devendra M. Amatya, USDA Forest Service, Center for Forested Wetlands Research, 3734 Highway 402, Cordesville, SC 29434; phone: 843-336-5612; fax: 843-336-5068; e-mail: damatya@fs.fed.us. set asides have decreased the industrial forest base for timber production, leading in some instances to more intensive silvicultural practices on the remaining forest land. Through time, the land use, hydrology, and ecosystem products and services of this mosaic have been modified to an extent that may jeopardize long-term sustainability.

Forests cover about one-third of the U.S. (Sedell et al., 2000; Jones et al., 2009), totaling about 300 million ha and making up about $7 \%$ of the world's forestland area (USDA, 2001). There are many different types of forests in the U.S., stretching from the subtropical forests in south Florida to boreal forests of Alaska, and from the deciduous and mixed forests of the eastern U.S. to the conifer-dominated forests of the west. These diverse ecosystems provide habitat for wildlife, help clean the air and water, and supply timber, fuelwood, and other harvested products, while serving our recreational needs as places for hiking, camping, hunting, and fishing. U.S. forests are the single largest producer of industrial timber in the world (Prestemon and Abt, 2002). Furthermore, about two-thirds of the nation's scarce freshwater resources originate on forested lands (Jones et al., 2009). Maintaining their functional integrity is fundamental to the sustainability of ecosystems and societies alike. However, there is increased recognition that forest management is needed to maintain forest, ecosystem, and watershed health and resilience.

Understanding watershed hydrology is critical to forest ecosystem management, as it drives nutrient cycling and loading dynamics in the soil, through plants, animals, precip- 
itation inputs, and surface and subsurface flow networks that support downstream water quality. Because forests make up a relatively large portion of many of our watersheds, it is important to understand the hydrology of both natural forests and silvicultural operations, while considering the contribution of other land uses. New activities and forest products often emerge in response to specific needs. Growth in biofuel demand could lead to increased removal of biomass from plantation forests, which would have substantial hydrologic impacts on these lands. In its first comprehensive forecast on southern forests, the U.S. Forest Service (2011) stated that urbanization, bioenergy use, weather patterns, land ownership changes, and invasive species will significantly alter the south's forests between the years 2010 and 2060. The area of forest land is projected to decrease by about 9.3 million ha. One of the report's key findings is that population growth will bring more runoff from impervious surfaces such as roads, buildings, and parking lots, as well as increased pollution, which will impact the quality of drinking water and aquatic habitats. Increased runoff can also affect channel morphology and reduce the baseflow needed to sustain water supplies and other uses, including aquatic life.

A large number of small field-scale experimental studies using a paired-catchment approach have been conducted to better understand forest hydrologic processes, their interactions with the environment, and their ecohydrologic impacts (Bosch and Hewlett, 1982; Sun et al., 2001; Jackson et al., 2004; Brown et al., 2005; Edwards and Troendle, 2008; Worrall et al., 2003; Elliott and Vose, 2005; Swank and Douglas, 1974). However, more than 90 years after the first pairedcatchment study at Wagon Wheel Gap, Colorado (Bates, 1921), forest hydrologists and natural resources managers are still working to fully understand the effects and the variances of forest management practices on hydrology and water quality (Zegre, 2008). The highly variable nature of catchment responses to disturbance, by harvesting, fire, insect and disease damage, or species replacement, depends on many factors, such as catchment scale, climate, forest and vegetation types, density, geology, soils, topography, elevation, aspect, disturbance location, and type of disturbance. Decades of field and experimental research have been conducted to evaluate the effects of disturbance on many different watershed attributes, and many different analysis methods have been developed and employed. Pairing of catchments offers the ability to identify roles of forest cover, internal watershed behavior, and climate variability to establish a "baseline" for reference (Zegre, 2008). This approach continues to be used on loworder watersheds as the primary method for impact assessments, although its validity for predicting effects on large flooding events had been recently challenged (Alila et al., 2009).

There has been increasing attention toward advancing the science of forest hydrology and its applications among research institutions and professional societies over the past century. Advances in computing, sensor, and information technology have accelerated this trend in the past few decades. Since early and relatively infrequent conferences of forest hydrologists and scientists such as Sopper and Lull (1967), several conferences and special issues on forest hydrology have been sponsored by various scientific organizations and institutions. Likewise, hydrology reference books have greatly increased in number since Chow's Handbook of Applied Hydrology (1964). Although in most instances, the basic tenets have not changed, our knowledge, information, and applications of them have grown substantially.

In the preface of a special collection of 26 papers on sustainability of U.K. upland forests, Neal et al. (2004) stated that growing emphasis on sustainable development is increasing the contribution of forests to multifunctional, sustainable environmental management. They further stressed that protection of freshwater is a key requirement of sustainable forestry, and high priority has been given to the development of guidelines for best management practices (BMPs) to achieve that goal across the U.K. The authors elaborated on what has been achieved, what uncertainties remain, and the scope for further improvement to meet future environmental challenges. Sun et al. (2008) provided an overview of a featured collection on forest hydrology in China. The central theme of the collection was to address how management, climate change, and variability affect watershed hydrology and forest-water relationships across a large physiographic gradient at multiple scales, ranging from hillslopes, to small watersheds, to continental China.

Buttle et al. (2000) published a summary of recent advances in Canadian forest hydrology. That article highlighted studies of hydrological processes across forest ecozones and hydrological responses to forest disturbance and recovery. Links between studies of hydrological processes in Canada's forests and other fields of research were examined, with particular attention to ongoing efforts to model hydrological impacts and interactions with the climate, biogeochemistry, geomorphology, and ecology of forested landscapes. Luce and Wemple (2001), in their lead article for a special issue entitled "Hydrologic and geomorphic effects of forest roads," suggested that the articles included would provide useful concepts and tools to professionals in charge of watershed protection. Ice and Stednick (2004) compiled a synthesis of watershed lessons from studies of forest and wildland ecosystems in the conterminous U.S. for the 20th century.

In addition to specialty conferences and collections, reports and books have also been devoted to forest hydrology in the past decade. For instance, the National Research Council (NRC, 2008), in its report on the present understanding of forest hydrology, made connections between forest management and attendant hydrologic effects. This report indicated that determining how to manage forests and sustain water supplies will be a primary challenge in the 21 st century. The report concluded that a strong evidence base has emerged for understanding basic processes and principles of water movement through forests that can be used to predict the general directions and magnitudes of hydrologic effects of changes in forest cover, climate, and land use. In addition, a recent book, Forest Hydrology and Biogeochemistry: Synthesis of Past Research and Future Directions, edited by Levia et al. (2011) synthesizes the current knowledge in forest hydrology and biogeochemistry, covering the fields of hydrology, biogeoscience, ecology, forestry, boundary-layer meteorology, and geography.

There is a continuing need to increase our understanding of forest hydrologic processes, their interaction with other land uses and environments, and their appropriate application at the watershed or basin scale. In 1988, the American Society of Agricultural Engineers (ASAE, now ASABE) organized an international symposium on modeling agricultural, forest, and rangeland hydrology (ASAE, 1988) with 
subsequent publication of the proceedings. Another ASABE specialty conference, focused on hydrology and management of forested wetlands, was held in New Bern, North Carolina, in 2006. The 60 papers in the proceedings covered a wide range of forest hydrologic issues, such as wetland hydrologic functions and processes, wetland restoration and BMPs, biogeochemical cycling and transport, innovative monitoring and modeling techniques, effects of drainage ditches on wetland hydrology, hydrology and water quality of forested wetlands at a watershed scale, sustainable management of forested wetlands, and effects of land use and climate change on hydrology and water quality (Williams and Nettles, 2006). Perhaps the greatest strength of these papers was their longterm examination of hydrology, with many studies spanning more than a decade of continuous data collection. Often, the impacts of management that seem highly destructive when viewed over a few years are nearly imperceptible after a decade of recovery. Since even decades of data are insufficient to examine climate change, both modeling and retrospective examinations are needed for their comprehensive analysis. Some of the articles appearing in this special collection are updates and extensions of research investigations presented in the 2006 ASABE specialty conference.

The main objective of this article is to introduce the 2011 ASABE Special Collection on Advances in Forest Hydrology and provide a brief review of the ten articles in this special issue, which focus on the hydrology of forest stands and watersheds primarily in the Atlantic Coastal plain, with particular focus on forests with high water table soils, within the context of sustainable water resources management.

\section{IsSues AdDRESSED IN THIS COLleCtion}

The articles in this special collection address some of the hydrologic issues important to forest ecosystems as identified above. The articles include information on the effects of management within riparian buffers on water table and ponding, anthropogenic and climatic effects on seepage wetlands, hydrologic modeling of a low-gradient coastal forest and for identification of wetland hydrology and interaction with plant ecology for wetland restoration, as well as effects of minor silvicultural drainage on wetland hydrology. In addition, one article evaluates methods for determining potential evapotranspiration (PET) for forests, and another investigates the significance of the LAI of emerging vegetation after harvest, which may have large implications on forest water balance, nutrient dynamics, and nutrient loading. Other articles report on the long-term hydrology and nutrient losses in drainage water from a managed pine forest, and the uncertainty associated with estimates of nutrient loading due to infrequent sampling.

\section{Forest Hydrologic Processes}

Sampson et al. (2011) report on six years of measured LAI of emergent vegetation using data from both clip plots and a LI-COR LAI 2000 Plant Canopy Analyzer following harvest, mechanical site preparation, and then planting pine on a 25 ha drained pine plantation. The authors found that the four-year post-harvest maximum LAI exceeded $8 \mathrm{~m}^{2} \mathrm{~m}^{-2}$ (projected area basis). Emergent vegetation dominated the site for nearly five years and likely exerted a strong influence on the site water balance and nutrient use during early stand development. The authors suggest that future hydrologic modeling studies should consider the effects of this emergent understory vegetation. Modeling needs for quantifying the impacts will be similar to those required for determining effects of intercropping bioenergy crops, such as switchgrass with pine, on water and energy balances.

Using long-term hydrometeorological data at the U.S. Forest Service Coweeta Hydrologic Laboratory in the southern Appalachians, Rao et al. (2011) contrast three common PET models (FAO-56 Grass Reference ET, Hamon's PET, and Priestley-Taylor PET) for two sites ( 12.5 and 13.5 ha) in the North Carolina Appalachian mountains. They compared PET estimates with actual evapotranspiration (AET) at multi-temporal scales to derive monthly correction factors for the first two methods using Priestly-Taylor (P-T) as the standard. The authors report that the P-T method gave the most reasonable estimates of forest PET for both watersheds based on the long-term AET estimates calculated as the difference of precipitation and streamflow. Annual PET estimates of the conifer plantation were higher than those of the native deciduous forest due to lower albedo (higher net radiation) in the former. Both of the abovementioned works have implications on accurate quantification of forest evapotranspiration (ET) dynamics likely influencing the water balance of agricultural landscapes.

\section{Forest Hydrologic Monitoring}

The water table is the primary source of streamflow, primarily the baseflow, in many low-gradient Coastal Plain streams; therefore, changes in precipitation pattern and land use may impact local habitat (Gurrieri et al., 2010) and downstream water supply. Tufford (2011) reports on some of the trends and water table responses in headwater seepage areas in the South Carolina Coastal Plain at daily, seasonal, and interannual time scales. Based on observed data at two groundwater well locations, the author suggests that the water table aquifer is a resource that requires explicit protection in the context of increased human development and uncertain trends in future precipitation.

In a long-term study on a 25 ha drained pine plantation, Amatya and Skaggs (2011) found the annual outflow varied from as low as $5 \%$ of annual precipitation in a very dry year to a high of $56 \%$ in a very wet year, with a mean of $32 \%$ over the 21 years of observation. The outflow was primarily subsurface drainage and was strongly correlated with annual precipitation. The outflows were higher $(59 \%$ of rainfall on average), more continuous, and of longer duration during the winter season. Although ET was generally not limited by soil moisture conditions on these shallow water table soils, there were exceptions in extremely dry years and during long dry periods in years with otherwise normal precipitation. Although nitrogen $(\mathrm{N})$ levels increased after commercial thinning (1988) and fertilization of the stand (1989), these levels declined substantially by 1995 . The annual concentrations of $\mathrm{N}$ ranged from 0.51 to $2.23 \mathrm{mg} \mathrm{L}^{-1}$ with a mean of $1.1 \mathrm{mg} \mathrm{L}^{-1}$, and total phosphorus (TP) ranged from 0.01 to $0.12 \mathrm{mg} \mathrm{L}^{-1}$ with a mean of $0.04 \mathrm{mg} \mathrm{L}^{-1}$. The average annual $\mathrm{N}$ loadings were $6.5( \pm 5.3) \mathrm{kg} \mathrm{ha}^{-1}$, and the average annual TP loadings were $0.17( \pm 0.11) \mathrm{kg} \mathrm{ha}^{-1}$. These long-term data may have some implications for assessment of the effects of land management on the hydrology and water quality of similar lands in the coastal region. 
Birgand et al. (2011) investigated the level of uncertainty induced by infrequent sampling on annual loads of a suite of nutrients in a 1500 ha forested and a 4000 ha mostly forested watershed within the lower Coastal Plain of North Carolina. Uncertainties depended on the watershed and the nutrient constituents of concern, but their level was generally found to be high, around or beyond $\pm 20 \%$ and $\pm 40 \%$ for weekly and monthly sampling for most nutrients. The uncertainty was attributed to the short periods of active flow and the flashiness of concentration variations. The results suggest that to obtain uncertainties of $\pm 2 \%$ for nitrogen species, it might be necessary to take more than 200 samples over six months of the year in similar watersheds of the eastern U.S.

\section{Forest Hydrologic Management}

Kolka et al. (2011) evaluated the effects of three types of upland harvesting on the hydrology of seasonal ponds at a site in north central Minnesota using a randomized block design of 6 ha size. These seasonal ponds, which function as small isolated wetlands, are integral components of the ecological landscape; however, they pose a management challenge in a forest setting. The results of the study indicate that upland harvesting of forest surrounding seasonal ponds does impact short-term pond hydrology, resulting in a rise of pond water level for four years after harvest, and that the type of buffer treatments, e.g., uncut or full or partial harvest, influences this impact. As much as five years were required for pond water levels to return to pre-harvest levels. The authors suggest that the amount of vegetation harvested within a riparian buffer affects the hydrologic response, especially in the first year following harvest. The results from this study should be useful in developing forest management guidelines for seasonal ponds commonly found in northern, glaciated, forested catchments.

Terrell et al. (2011) evaluated the effectiveness of current southeastern BMPs by measuring hydrology and sediment transport in four southwest Georgia headwater streams during pre-harvest, post-harvest, and post-site preparation periods. The authors found no significant change in peak flow behavior nor in total suspended solids (TSS) as a result of post-harvest or post-site preparation. Increased concentrated overland flow entering the streamside management zones (SMZs) in some occurrences after harvest was reduced to pretreatment levels within two years following harvest. The authors conclude that the current forestry BMPs were effective in preventing sediment increases due to harvest and site preparation at these sites.

\section{Forest Hydrologic Modeling}

Caldwell et al. (2011) describe how hydrologic models, such as DRAINMOD (Skaggs, 1978), can be used to characterize the long-term hydrology of wetland communities (pond pine woodland, nonriverine swamp forest, high pocosin, and bay forest) commonly found in the Atlantic Coastal Plain and their application to define wetland design criteria for restoring such wetlands. The goal of wetland restoration is to regain wetland functions by returning the hydrology and vegetative communities of disturbed wetland sites to their natural condition. Using the modeling results of daily water table depths and soil organic layer thickness for sites varying in size from 145 ha to 808 ha, the authors developed design criteria linking soil, vegetation, and hydrology parameters that should contribute to improved wetland restoration success.

Skaggs et al. (2011) present the results of long-term DRAINMOD simulations to determine the impacts of minor drainage for silviculture on wetland hydrology. Simulations were conducted for 13 soil types for sites in the Atlantic and Gulf coastal plains to determine the threshold drainage intensity (ditch depth and spacing) that removes wetland hydrology from forested wetlands. The authors developed threshold ditch spacings for combinations of soils and locations that can be used as benchmarks to directly evaluate the impact of drainage alternatives on wetland hydrology. The authors concluded that more work is needed to define $T_{25}$ values (time required for the water table to drawn down by drainage to $25 \mathrm{~cm}$ depth) for a range of surface storages, including those smaller values needed for application to agricultural cropland. The $T_{25}$ values can be used to determine lateral impacts for multiple combinations of ditch depths and soils.

The widely used SWAT model (Arnold et al., 1998; Gassman et al., 2007; Douglas-Mankin et al., 2010) using a oneparameter depletion coefficient to account for antecedent moisture in the curve number $(\mathrm{CN})$ approach, was evaluated for the first time on a fully forested, 7260 ha lower coastal plain watershed in South Carolina by Amatya and Jha (2011) in this issue. The authors conclude that, based on limited field calibration, the model was able to predict the daily and monthly streamflow dynamics of this watershed reasonably well on shallow, poorly drained soils. However, the model was unable to capture the dynamics of flow events following a long drought with deep water tables and substantial profile storage and also for events preceded by very wet antecedent conditions. The authors conclude that, in addition to enhancements in other parameter estimates, a further modification of SWAT by including a water table position as a surrogate for soil moisture may help more accurately predict the flow dynamics, as was suggested by La Torre Torres et al. (2011) for this site. This work may have implications in assessing accurate water balances of similar watersheds of lowgradient, poorly drained lands using the SWAT model.

\section{SUMMARY, RECOMMENDATIONS, AND Future Directions}

Water from forested landscapes is critical for supporting a wide variety and various scales of ecological systems and surrounding communities. Research provides information that helps forest and water resource managers understand the influence of various interactions and pressures, including that of land use and climate change, on hydrology and water quality. Sound science is needed to support wise decisions and appropriate responses to contentious water policy issues (SFRP, 2011). Jones et al. (2009) concluded that forest hydrology, the study of how water flows and recycles through forests, can help illuminate connections between forests and water, but it must advance to address current complex issues, including climate change, wildfires, changing patterns of development and ownership, and changing societal values. The authors also emphasized a need to address forest hydrology as a landscape hydrology that embraces the interactive effects of various land-based activities on water supplies. The authors cited these as the main conclusions of a recent report by the National Research Council (NRC, 2008). Much atten- 
tion will be given to light detecting and ranging (LiDAR) technology for its ability to identify fine detail in stream channel networks and boundary conditions (James et al., 2007). Minor hydrological modifications, such as ditches, terraces, dikes, gullies, relocated streams, etc., become evident as to their location and potential effect. In this context, additional research is needed to advance our current understanding of forest hydrologic processes, especially the detail of stream networks, topographic depressions, floodplain and wetland functions, preferential flow characteristics into and within the forest soil profile, shallow and deep water table influences, flow generation in low-gradient watersheds, and the ET process for various forest types and species including the understory, which has received limited attention in the literature. An accurate understanding of these processes in a reference forest system is critical to the evaluation of impacts of all disturbances to the system. Recent advancements in monitoring and mapping technology together with computing speed should also be used as opportunities to address these complex processes.

The articles in this special collection deal with issues from processes to impacts to BMPs on first-order size (6 ha) to medium-scale (6th level HUC size) subwatersheds (7260 ha). Eight of the articles focus on study sites in the Atlantic and or Gulf coastal plains. One deals with methods to predict forest ET in the Appalachian Mountains. Two articles present results of studies of the hydrologic effects of harvesting and associated BMPs. Four articles are related to the hydrology of ponds and wetlands, and their restoration. Two articles deal with sediment and/or nutrients from forested lands. Four articles use long-term analysis, either with measured data or with simulation results. Three articles use models to describe forest hydrology and its application: two of them apply DRAINMOD (Skaggs, 1978) to evaluate wetland hydrology as related to plant communities and minor ditch drainage, and one uses SWAT to predict streamflow dynamics. In the following paragraphs, we provide below recommendations for additional studies that could be conducted in the near future to address other contemporary forest hydrologic issues in large prior converted (PC) agricultural landscapes.

The SCS-CN method is widely used to describe the surface runoff process in SWAT and in other models. However, the availability of $\mathrm{CN}$ values is very limited for the complex mosaic of forest cover, including harvesting, thinning, various species, and stand ages of the overstory and understory that may have varying canopy storage, surface depressions, and roughness, all of which potentially affect runoff. A modified $\mathrm{CN}$ and/or linkage with a groundwater table module should be applied in these models to better describe the effects of antecedent conditions on the hydrology of lowgradient forest watersheds.

The importance of forests in the PC agricultural landscape is often not reflected by its proportional area. For example, it is well recognized that filter strips and conservation buffers around streams draining agricultural catchments reduce nonpoint-source pollution from those lands. Headwaters of streams in a landscape are generally forested and play a critical role in sustaining water quantity and quality. Forests in the landscape also play a critical role in net ecosystem water and nutrient balance, flood attenuation, carbon sequestration, and greenhouse gas emissions, all of which may be affected by climate change. In order to improve the efficiency and effectiveness of designing landscape functions to ensure sustain- ability, models commensurate with those available for agricultural lands are needed to characterize the biological, chemical, and physical processes of forested lands.

The SCS CN method, SWAT, AGNPS, GLEAMS, DRAINMOD, EPIC, ANSWERS, and REMM are examples of models and tools that agricultural engineers and scientists have developed for sustainable management of food and fiber. These models, developed primarily for agricultural catchments, are routinely applied on landscapes that involve forests (Amatya and Jha, 2011; Khanal et al., 2011) and other land uses (Bosch et al., 2004; Wu and Xu, 2006). Their reliability for assessing the impacts of BMPs is heavily dependent on the understanding of forest hydrologic and biogeochemical processes, which, in most cases, was not a primary focus of the underlying research and model development. The fact that the hydrology and water quality of undisturbed forested lands is generally used as a baseline reference for determining the impacts of BMPs adds further emphasis to the importance of testing and, where necessary, further developing models for application to forested catchments. An example is the new DRAINMOD-Forest model (Tian et al., 2010), which was developed and successfully tested (Tian et al., 2012) on a drained pine forest. In addition to predicting the hydrology and impact of water management and silvicultural practices, the model predicts tree growth (primary production) and the dynamics of nitrogen and carbon. Similarly, Liu et al. (2007) integrated the Riparian Ecosystem Management Model (REMM; Inamdar et al., 1999a, 199b) with the SWAT model using a GIS interface to quantify the water quality benefits of buffers in agricultural watersheds. However, it is important to test these models for a wide range of climatic and site conditions for their effective application in predicting the hydrology, water quality as well as the effects of the riparian buffer.

Technologies (e.g., sensors, Doppler radar, LIDAR, and satellite images) used in interpretation and model parameterization of the topography, soils, land use/land cover, hydrometeorology, and vegetation parameters are generally the same for both agricultural crops and forests (Amatya et al., 2009). However, the relationships between forest ecohydrologic processes and remote sensing products are often poorly understood, leading to errors in model inputs and limiting the reliability of their application.

Future studies related to forest hydrology and its applications should address issues on larger spatial scales, including larger-scale contemporary water resource issues (e.g., water supply, instream flow, floods, droughts, beneficial water uses), the impacts of climate and land use changes (Sun et al., 2005a, 2005b; Dai et al., 2011), and modern BMPs to mitigate the effects for sustainable management, while taking into account the uncertainties in the variability of field circumstances, measurements, and modeling approaches (Harmel et al., 2010). For example, Lockaby et al. (2011) reported that water stress will likely increase significantly by 2050 under four climate change scenarios, largely because higher temperatures will result in more water loss by ET and because of decreased precipitation in some areas. However, the degree to which we can estimate changes in vegetation type with new ET requirements are speculative at best. The same authors also concluded that water stress due to the combined effects of population and land use change will increase by $10 \%$, on average, in the south by 2050 . Additional research is needed to identify innovative solutions and methodologies 
for mitigating potential impacts of climate and land use change for sustainable management of water resources on large PC agricultural landscapes that include forested catchments. Furthermore, research needs also include better information about quantification of relationships between ecosystem attributes and forest management, including biomass production and harvest in a multi-dimensional context (Loehle et al., 2009).

One way to address these issues is to extend and strengthen the close collaboration of agricultural and biological engineers with hydrologists, soil scientists, biologists, ecologists, silviculturists, and tree physiologists to develop better understanding of the ecosystem and improved methods for quantifying the processes and their inter-relationships. Such collaborations may include sharing long-term ecohydrological data from experimental watersheds across the geographical gradients in the country, such as those maintained by the USDA Agricultural Research Service and the Forest Service. Some land grand universities and even the forest industries have experimental watershed information and studies. The most effective way to address the other contemporary scientific questions and management challenges relative to forest hydrology in the ever-changing PC agricultural landscape is through collaboration among academia, industries, state and federal government agencies, private land owners, and nongovernmental organizations, including the Consortium of Universities for the Advancement of Hydrologic Science, Inc. (CUAHSI), to build and share a long-term ecohydrological database, identify new prioritized issues, conduct experimental studies, commit resources, and implement the recommended science and technology using appropriate technology transfer approaches.

\section{ACKNOWLEDGEMENTS}

This article introduces the ten articles in the 2011 Special Collection on Advances in Forest Hydrology published by the Soil and Water Division of ASABE in this issue of Transactions of the ASABE. The authors would like to thank the ASABE publications staff, associate editors, and reviewers for their contributions to and timely management of the review process. The authors also wish to thank all the contributing authors for sharing their results, information, data, and tools in advancing and enriching the current knowledge on forest hydrology, management, and its application through each of the articles. The authors would also like to acknowledge Dr. Johnny Grace, Research Engineer at the U.S. Forest Service, Southern Research Station Forest Operations Research Unit, Auburn, Alabama, and William Hansen, Forest Hydrologist at the U.S. Forest Service Francis Marion and Sumter National Forests, Columbia, South Carolina, for their valuable comments and suggestions for the manuscript of this article.

\section{REFERENCES}

Alila, Y., P. K. Kuras, M. Schnorbus, and R. Hudson. 2009. Forests and floods: A new paradigm sheds light on age-old controversies. Water Resources Res. 45(8): W08416.

Amatya, D. M., and M. K. Jha. 2011. Evaluating the SWAT model for a low-gradient forested watershed in coastal South Carolina. Trans ASABE 54(6):2151-2163.
Amatya, D. M., and R. W. Skaggs. 2011. Long-term hydrology and water quality of a drained pine plantation in North Carolina. Trans ASABE 54(6): 2087-2098.

Amatya, D. M., R. W. Skaggs, and C. C. Trettin. 2009. Advancing the science of forest hydrology: A challenge to agricultural and biological engineers. Resource 16(5) (July-August): 10-11. St. Joseph, Mich.: ASABE.

Arnold, J. G., R. Srinivasan, R. S. Muttiah, and J. R. Williams. 1998. Large-area hydrological modeling and assessment. Part I: Model development. J. American Water Resour. Assoc. 34(1): 73-89.

ASAE. 1988. Modeling Agricultural, Forest, and Rangeland Hydrology: Proceedings of the International Symposium. St. Joseph, Mich.: ASAE.

Bates, C. G. 1921. First results in the streamflow experiment, Wagon Wheel Gap, Colorado. J. Forestry 19(4): 402-408.

Birgand, F., T. Appelboom, G. Chescheir, and W. Skaggs. 2011. Estimating nitrogen, phosphorus, and carbon fluxes in forested and mixed-use watersheds of the lower coastal plain of North Carolina: Uncertainties associated with infrequent sampling. Trans ASABE 54(6): 2099-2110.

Bosch, D. D., J. M. Sheridan, H. L. Batten, and J. G. Arnold. 2004. Evaluation of the SWAT model on a coastal plain agricultural watershed. Trans. ASAE 47(5): 1493-1506.

Bosch, J. M., and J. D. Hewlett. 1982. A review of catchment experiments to determine the effect of vegetation changes on water yield and evapotranspiration. J. Hydrol. 55(1-4): 3-23.

Brown, A. E., L. Zhang, T. A. McMahon, A. W. Western, and R. A. Vertessey. 2005. A review of paired catchment studies for determining changes in water yield resulting from alterations in vegetation. J. Hydrol. 310(1-4): 28-61.

Buttle, J. M., I. F. Creed, and J. W. Pomeroy. 2000. Advances in Canadian forest hydrology (1995-1998). Hydrol. Proc. 14(9): 1551-1578.

Caldwell, P., M. Vepraskas, J. Gregory, W. Skaggs, and R. Huffman. 2011. Linking plant ecology and long-term hydrology to improve wetland restoration success. Trans ASABE 54(6): 2129-2137.

Chow, V. T. 1964. Handbook of Applied Hydrology. New York, N.Y.: McGraw-Hill.

Dai, Z., D. Amatya, G. Sun, C. Trettin, C. Li, and H. Li. 2011. Climate variability and its impact on forest hydrology on South Carolina coastal plain, USA. Atmosphere 2(3): 330-357.

Douglas-Mankin, K. R., R. Srinivasan, and J. G. Arnold. 2010. Soil and Water Assessment Tool (SWAT) model: Current developments and applications. Trans. ASABE 53(5): 14231431.

Edwards, P., and C. A. Troendle. 2008. Water yield and hydrology. In Cumulative Watershed Effects of Fuels Management. L. J. Audin, ed. Newton Square, Pa.: U.S. Forest Service,

Northeastern Area. Available at: www.na.fs.fed.us/fire/cwe.shtm. Accessed 15 June 2009.

Elliott, K. J., and J. M. Vose. 2005. Initial effects of prescribed fire on quality of soil solution and streamwater in the southern Appalachian Mountains. Southern J. Appl. Forestry 29(1): 5-15.

Gassman, P. W., M. R. Reyes, C. H. Green, and J. G. Arnold. 2007. The Soil and Water Assessment Tool: Historical development, applications, and future research directions. Trans. ASABE 50(4): 1211-1250.

Gurrieri, J., C. Carlson, M. Coles-Ritchie, K. Dwire, S. Solem, A. Aldous, D. Amatya, T. Carroll, B. Johnston, A. Rorick, and L. A. Spencer. 2010. Groundwater dependent ecosystems: Inventory and monitoring protocol development for National Forest Service lands. In Abstracts of the 2010 Annual Meeting of Society of Wetland Scientists. Madison, Wisc.: Society of Wetland Scientists.

Harmel, R. D., P. K. Smith, and K. W. Migliaccio. 2010. Modifying goodness-of-fit indicators to incorporate both measurement and 
model uncertainty in model calibration and validation. Trans. ASABE 53(1): 55-63.

Ice, G. G., and J. D. Stednick, eds. 2004. A Century of Forest and Wildland Watershed Lessons. Bethesda, Md.: Society of American Foresters.

Inamdar, S. P., J. M. Sheridan, R. R. Lowrance, R. G. Williams, D. D. Bosch, L. S. Altier, and D. L. Thomas. 1999a. Riparian Ecosystem Management Model (REMM): I. Testing of the hydrology component for a coastal plain riparian system. Trans. ASAE 42(6): 1679-1689.

Inamdar, S. P., R. R. Lowrance, L .S. Altier, R. G. Williams, and R. K. Hubbard. 1999b. Riparian Ecosystem Management Model (REMM): II. Testing of the water quality and nutrient cycling component for a coastal plain riparian system. Trans. ASAE 42(6): 1691-1707.

Jackson, C. R., G. Sun, D. M. Amatya, W. T. Swank, M. Riedel, J. Patric, T. Williams, J. M. Vose, K. Trettin, W. M. Aust, S. Beasely, H. Williston, and G. Ice. 2004. Fifty years of forest hydrology research in the southeast: Some lessons learned. In $A$ Century of Forest and Wildland Watershed Lessons, 33-112. J. Stednick and G. Ice, eds. Society of American Foresters.

James, L. A., D. G. Watson, and W. F. Hansen. 2007. Using LiDAR data to map gullies and headwater streams under forest canopy: South Carolina, USA. Catena 71(1): 132-144.

Jones, J. A., G. L. Achterman, L. A. Augustine, I. F. Creed, P. F. Ffolliott, L. MacDonald, and B. C. Wemple. 2009. Hydrologic effects of a changing forested landscape: Challenges for hydrological sciences. Hydrol. Proc. 23(18): 2699-2704.

Khanal, S., P. B. Parajuli, and J. Hatten. 2011. Evaluating hydrologic effect of forest harvesting at upper Pearl River watershed in Mississippi. ASABE Paper No. 1110895. St. Joseph, Mich.: ASABE.

Kolka, R., B. Palik, D. Tersteeg, and J. Bell. 2011. Effects of riparian buffers on hydrology of northern seasonal ponds. Trans ASABE 54(6): 2111-2116.

La Torre Torres, I., D. M. Amatya, T. J. Callahan, and G. Sun. 2011. Seasonal rainfall-runoff relationships in a lowland forested watershed in the southeastern USA. Hydrol. Proc. 25(13): 2032-2045.

Levia, D. F., D. Carlyle-Moses, and T. Tanaka, eds. 2011. Forest Hydrology and Biogeochemistry: Synthesis of Past Research and Future Directions. Ecological Studies 216. 1st ed. Dordrecht, The Netherlands: Springer.

Liu, Y., W. Yang, and X. Wang. 2007. GIS-based integration of SWAT and REMM for estimating water quality benefits of riparian buffer in agricultural watersheds. Trans. ASABE 50(5): 1549-1563.

Lockaby, G., C. Nagy, J. M. Vose, C. R. Ford, G. Sun, S. McNulty, P. Caldwell, E. Cohen, and J. M. Meyers. 2011. Chapter 13: Water and forests. In Southern Forests Futures Project. Asheville, N.C.: U.S. Forest Service, Southern Research Station. Available at: www.srs.fs.usda.gov/futures/reports/draft/ Frame.htm.

Loehle, C., T. B. Wigley, E. Schilling, V. Tatum, J. Beebe, E. Vance, P. V. Deusen, and P. Weatherford. 2009. Achieving conservation goals in managed forests of the southeastern coastal plain. Environ. Mgmt. 44(6): 1136-1148.

Luce, C. H., and B. C. Wemple. 2001. Introduction to special issue on hydrologic and geomorphic effects of forest roads. Earth Surf. Proc. Landforms 26(2): 111-113.

Neal, C., S. Ormerod, S. Langan, T. Nisbet, and J. Roberts. 2004. Sustainability of UK upland forestry: Contemporary issues for the protection of freshwaters (Special issue preface). Hydrol. Earth Syst. Sci. 8(3): 277-278.

NRC. 2008. Hydrologic effects of a changing forested landscape. Washington, D.C.: National Research Council.

Prestemon, J., and R. Abt. 2002. Chapter 13: Timber products supply and demand. In Southern Forest Resource Assessment,
299-325. D. Wear and J. Greis, eds. Asheville, N.C.: U.S. Forest Service, Southern Research Station.

Rao, L., G. Sun, C. Ford, and J. Vose. 2011. Modeling potential evapotranspiration of two forested watersheds in the southern Appalachians. Trans ASABE 54(6): 2067-2078.

Sampson, D. A., D. M. Amatya, C. D. Blanton, and R. W. Skaggs. 2011. Leaf area index (LAI) of loblolly pine and emergent vegetation following a harvest. Trans ASABE 54(6): 2057-2066.

Sedell, J., M. Sharpe, D. D. Apple, M. Copenhagen, and M. Furniss. 2000. Water and the Forest Service. Washington, D.C.: U.S. Forest Service.

SFRP. 2011. Southern Forestry Research Compendium: A Summary of Southern Forest Researchers and Research Focus Areas. Monroe, Ga.: Southern Forest Research Partnership.

Skaggs, R. W. 1978. A water management model for shallow water table soils. Report No. 134. Raleigh, N.C.: North Carolina State University, Water Resources Research Institute.

Skaggs, R. W., B. Phillips, G. Chescheir, and C. Trettin. 2011. Effect of minor drainage on hydrology of forested wetlands. Trans ASABE 54(6): 2139-2149.

Sopper, W. E., and H. W. Lull, eds. 1967. International Symposium on Forest Hydrology. Oxford, U.K.: Pergamon Press.

Sun, G., S. G. McNulty, J. P. Shepard, D. M. Amatya, H. Riekerk, N. B. Comerford, R. W. Skaggs, and L. Swift Jr. 2001. Effects of timber management on hydrology of wetland forests in the southern United States. Forest Ecol. and Mgmt. 143(1-3): 227236.

Sun, G., S. G. McNulty, J. Lu, D. M. Amatya, Y. Liang, and R. K. Kolka. 2005a. Regional annual water yield from forest lands and its response to potential deforestation across the southeastern United States. J. Hydrol. 308(1-4): 258-268.

Sun, G., S. G. McNulty, E. Cohen, J. Moore Myers, and D. Wear. 2005b. Modeling the impacts of climate change, land use change, and human population dynamics on water availability and demands in the southern U.S. ASABE Paper No. 052219. St. Joseph, Mich.: ASABE.

Sun, G., S. Liu, Z. Zhang, and X. Wei. 2008. Forest hydrology in China: Introduction to the featured collection. J. American Water Resour. Assoc. 44(5): 1073-1075.

Swank, W. T., and J. E. Douglass. 1974. Streamflow greatly reduced by converting deciduous hardwood stands to pine. Science 185(4154): 857-859.

Terrell, S., W. Summer, R. Jackson, M. Miwa, and D. Jones. 2011. Harvest, site preparation, and firebreak effects on hydrology and sediment transport in coastal plain headwater streams. Trans ASABE 54(6): 2117-2127.

Tian, S., M. A. Youssef, R. W. Skaggs, D. M. Amatya, and G. M. Chescheir. 2010. Field evaluation of the forestry version of DRAINMOD-N II model. In Proc. 9th Intl. Drainage Symposium at the XVIIth World Congress of CIGR. G. M. Chescheir and M. A. Youssef, eds. St. Joseph, Mich.: ASABE.

Tian, S., M. A. Youssef, R. W. Skaggs, D. M. Amatya, and G. M. Chescheir. 2012. Modeling water, carbon, and nitrogen dynamics for two drained pine plantations under intensive management practices. Forest Ecol. and Mgmt. 264: 20-36, doi:10.1016/j.foreco.2011.09.041.

Tufford, D. 2011. Shallow water table response to seasonal and interannual climate variability. Trans ASABE 54(6): 2079-2086.

USDA. 2001. Forests: The potential consequences of climate variability and change. A report of the National Forest Assessment Group for the U.S. Global Change Research program. Washington, D.C.: USDA Global Change Program Office.

U.S. Forest Service. 2011. Forest Service unveils first comprehensive forecast on southern forests. Asheville, N.C.: U.S. Forest Service Southern Research Station. Available at: www.srs.fs.usda.gov/news/472.

Williams, T. M., and J. E. Nettles, eds. 2006. Hydrology and Management of Forested Wetlands: Proceedings of the 
International Conference. St. Joseph, Mich.: ASABE. Available at: http://asae.frymulti.com/conference.asp? confid=hmfw2006.

Worrall, F., W. T. Swank, and T. P. Burt. 2003. Changes in stream nitrate concentrations due to land management practices, ecological succession, and climate: Developing a systems approach to integrated catchment response. Water Resour. Res. 39(7): 1177, doi: 10.1029/2000WR000130.
Wu, K., and Y. J. Xu. 2006. Evaluation of the applicability of the SWAT model for coastal watersheds in southeastern Louisiana. J. American Water Resour. Assoc. 42(5): 1247-1260.

Zegre, N. 2008. The history and advancement of change detection methods in forest hydrology. In Society of American Foresters Water Resources Working Group Newsletter (December 2008). Bethesda, Md.: Society of American Foresters. 